\title{
Article \\ Collagen-Based Bioactive Bromelain Hydrolysate from Salt-Cured Cod Skin
}

\author{
Ezequiel R. Coscueta *(D), María Emilia Brassesco (D) and Manuela Pintado*
}

Citation: Coscueta, E.R.; Brassesco, M.E.; Pintado, M. Collagen-Based Bioactive Bromelain Hydrolysate from Salt-Cured Cod Skin. Appl. Sci. 2021, 11, 8538. https://doi.org/ 10.3390/app11188538

Academic Editor: Vincenza Ferraro

Received: 5 August 2021

Accepted: 10 September 2021

Published: 14 September 2021

Publisher's Note: MDPI stays neutral with regard to jurisdictional claims in published maps and institutional affiliations.

Copyright: (c) 2021 by the authors. Licensee MDPI, Basel, Switzerland. This article is an open access article distributed under the terms and conditions of the Creative Commons Attribution (CC BY) license (https:// creativecommons.org/licenses/by/ $4.0 /)$.
CBQF-Centro de Biotecnologia e Química Fina-Laboratório Associado, Universidade Católica Portuguesa, Escola Superior de Biotecnologia, Rua Diogo Botelho 1327, 4169-005 Porto, Portugal; mbrassesco@ucp.pt

* Correspondence: ecoscueta@ucp.pt (E.R.C.); mpintado@ucp.pt (M.P.); Tel.: +351-225-580-001 (ext. 8047) (E.R.C.)

\begin{abstract}
Considerable amounts of fish processing by-products are discarded each year. About $30 \%$ of this material may be skin and bone. Fish skin has more than $80 \%$ of its total protein content as collagen. Furthermore, in recent years, there has been a growing demand for collagen-based peptides due to their beneficial health effects. So, the objective of the present study was to optimise the obtaining bioactive hydrolysates from salt-cured cod skin using the protease Bromelain at $0.5 \%$ $(w / w)$ concentration. This study developed a sustainable process that consumes less time and energy and uses an alternative source as raw material. In addition, bromelain allows hydrolysates with important antioxidant (ORAC, $514 \mu \mathrm{mol}$ Trolox Equivalent/g protein) and antihypertensive activities (inhibition of $\mathrm{ACE}, \mathrm{IC}_{50}$ of $166 \mu \mathrm{g}$ protein $/ \mathrm{mL}$ ) as well as excellent biocompatibility with dermal and subcutaneous cells.
\end{abstract}

Keywords: Atlantic cod skin; enzymatic hydrolysis; collagen; fishery by-products; bioactive peptides; bromelain; antioxidant; antihypertensive

\section{Introduction}

Collagen is a structural protein present in different animal tissues. Its technological properties have been fundamental to various industries, and currently, its interest has increased due to its potential bioactive properties. Partial hydrolysis of native collagen produces gelatine, which is the usual collagen prepared industrially. Collagen and gelatine have different industrial applications; among the most well-known are the food, cosmetic, and biomedical industries [1]. In recent years, the demand for collagen-based peptides has grown dramatically. This is mainly due to the beneficial effects of these compounds on the skin. Oral ingestion of collagen-based peptides (generally gelatine hydrolysates) has been seen to promote collagen synthesis in the skin, increasing the size of collagen fibrils in the dermis. This is believed to improve skin hydration and prevent wrinkles [2]. Collagen-derived peptides also have antihypertensive and antioxidant activities that are associated with low molecular weight peptide structures [3]. Collagen-rich hydrolysates can be produced by controlled thermal or enzymatic hydrolysis [4]. However, enzymatic hydrolysis is preferred because it produces the material in its native state and needs less time and milder conditions to obtain lower molecular weight peptides [5]. Several enzymes have been used for the hydrolysis process [6-9]. However, the protein hydrolysates prepared using bromelain showed higher antioxidant capacity, desired functional properties, and excellent industrial applications [10-12]. The industrial production of collagen-derived peptides requires two coupled steps [13]. In the first, collagen is extracted and purified. In the second step, the peptides are obtained by enzymatic hydrolysis, they are sterilised, and finally they are dried [13]. Therefore, collagen extraction is time and energy consuming [2].

Classically, collagen is obtained from skins of mammalian and filamentous tissues but with several negative aspects. In recent years, due to the outbreak of animal diseases such as Bovine Spongiform Encephalopathy, Transmissible Spongiform Encephalopathies, and Foot and Mouth Disease, the search for alternative sources of collagen has increased [14]. The 
increase in fish consumption per capita and the consequent increase in fisheries by-products in the past two decades led academia and the industry to explore marine by-products as a reliable and economical source of many healthy and biologically active compounds such as collagen [15]. It includes marine fish, starfish, sponges, jellyfish, squid, etc. [16-19]. Fish residues may account for an average of $55 \%$ of the total fish weight; of this material, up to $30 \%$ may be skin and bone [17]. Fish skin has more than $80 \%$ of its total protein content as collagen. The work performed to date proves that marine fish may be a promising source.

This study aims to develop a new integrated methodology to produce a collagen-rich enzymatic hydrolysate, taking advantage of the salt-cured cod skin a by-product from cod industry abundant in countries such as Portugal.

\section{Materials and Methods}

\subsection{Materials}

Salt-cured cod skin (SCCS) from Atlantic cod (Gadus morhua) was kindly provided by Pascoal \& Filhos S.A. The skin was obtained as a by-product before the cutting and processing fish meat to obtain different portions to sell or for ready to eat meals. The samples were transported at room temperature and stored at $-20^{\circ} \mathrm{C}$ before processing. Calfskin type-I collagen was purchased from Sigma-Aldrich (St. Louis, MO, USA), and molecular weight marker was purchased from NZYTech, Lisboa, Portugal. Cod skin collagen was purified by acid methodology in previous work [20]. For the enzymatic hydrolysis, the commercial enzymes collagenase from Clostridium histolyticum (CHC), which is a protease specific for collagen and the cysteine protease Bromelain from pineapple stem (BR) were purchased from Sigma-Aldrich (St. Louis, MO, USA) with a declared activity of $\geq 125 \mathrm{CDU} / \mathrm{mg}$ solid (CDU $=$ collagen digestion units) and 3.98 units $/ \mathrm{mg}$ protein (one unit release $1.0 \mu \mathrm{mol}$ of $p$ nitrophenol from $n$-alpha-CBZ-L-Lysine $p$-nitrophenyl ester per minute at $\mathrm{pH} 4.6$ at $25^{\circ} \mathrm{C}$ ), respectively. MEM non-essential amino acid solution was supplied by Sigma-Aldrich (Merck, Darmstadt, Germany). Dulbecco's Modified Eagle Medium (DMEM) high glucose and Penicillin-Streptomycin mixture were obtained from Lonza (Basel, Switzerland). Foetal bovine serum (FBS) was purchased from Biowest (Nuaillé, France). All the other reagents were of analytical grade and used without further purification.

\subsection{Pre-Treatment of Skin}

The pre-treatment of skin was carried out following the methodology of Arumugam et al. [21], with some modifications. First, the cod skins were washed with tap water 3 times at $25{ }^{\circ} \mathrm{C}$ to remove the salt, residual fat, and flesh of fish (by the action of high salt concentration) and then cut into small pieces. Then, those pieces were mixed with $0.1 \mathrm{M}$ $\mathrm{NaOH}$ at $25^{\circ} \mathrm{C}$ to remove non-collagenous proteins and pigments at a sample-to-solution ratio of 1:10 $(w / v)$, about $4 \mathrm{~h}$. The mixture was centrifuged (Hettich Universal 320R) at $3857 \mathrm{RCF}$ for $15 \mathrm{~min}$ at $4{ }^{\circ} \mathrm{C}$. The resulting solid residue was washed with distilled water 5 times until neutral ( $\mathrm{pH} 7)$ at $25^{\circ} \mathrm{C}$ and then centrifuged according to the conditions described above.

\subsection{Preliminary Analysis}

The obtaining of collagen-rich hydrolysate with a plant enzyme such as BR was evaluated compared with the activity of $\mathrm{CHC}$ under similar conditions $\left(37^{\circ} \mathrm{C}, \mathrm{pH} 7.2\right)$ for $16 \mathrm{~h}$.

\subsection{Degree of Hydrolysis Analysis}

The degree of hydrolysis $(\mathrm{DH})$ was determined using the method described by Nielsen, Petersen and Dambmann (2001) [22], with some modifications [23]. 


\subsection{Yield of Production}

The yield was calculated as the percentage ratio of skin mass in gram to the hydrolysates mass obtained in $\mathrm{g}$, all on a dry basis.

$$
\text { Yield }(\%)=\frac{\text { Mass of the hydrolysate }(\mathrm{g})}{\text { Mass of the total skin hydrolysis }(\mathrm{g})} * 100
$$

For the mass of the hydrolysate, the mass equivalent to the saline content remaining in the solution, the residual acetate, was subtracted.

\subsection{Protein Concentration}

The protein concentration was measured by the Pierce BCA Protein Assay kit (Thermo Scientific, Waltham, MA, USA), using bovine serum albumin as standard.

\subsection{Tricine-SDS-PAGE}

Tricine-SDS-PAGE [24] was prepared using 6\% stacking and $12 \%$ resolving gel. $1.0 \mathrm{mg} / \mathrm{mL}$ Calfskin type I collagen, initial time and $30 \mathrm{~min}$ of the hydrolysis with bromelain, collagenase, and control (without enzymes) were mixed in $0.5 \mathrm{M}$ acetic acid, diluted $\frac{1}{2}$ with sample buffer, incubated at $80^{\circ} \mathrm{C}$ for $20 \mathrm{~min}$, and centrifuged at $21,382 \mathrm{RCF}$ for $10 \mathrm{~min}$. Twenty microliters of supernatants were loaded in gel. The electrophoresis ran at a constant voltage of $75 \mathrm{~V}$ for about $5 \mathrm{~min}$ followed by $150 \mathrm{~V}$. After electrophoresis, the gel was stained in Coomassie blue G-250 $(0.25 \%, w / v)$, staining solution for $1 \mathrm{~h}$, and discoloured overnight. The final image was acquired with the ChemiDoc ${ }^{\mathrm{TM}} \mathrm{XRS}+$ and analysed by the Imaging System Image Lab ${ }^{\mathrm{TM}}$ Software Version 6.0.1.34.

\subsection{Hydrolysis Optimisation}

An integrative process to produce bioactive hydrolysates from SCCS was developed and optimised. The hydrolysis process was optimised following for each experiment the same steps described in Scheme 1 (Optimised process). A multifactor experimental arrangement was designed following the Box Behnken model. Three experimental factors were considered, and three responses were analysed. The factors evaluated were $\mathrm{pH}$ value $\left(\mathrm{X}_{\mathrm{A}}\right)$, temperature $\left(\mathrm{X}_{\mathrm{B}}\right)$, and hydrolysis time $\left(\mathrm{X}_{\mathrm{C}}\right)$ and the selected response variables $(\mathrm{Y})$ were the protein concentration, antioxidant activity, and antihypertensive activity. The design resulted in an arrangement of 15 treatments, which was executed in triplicate (45 runs) on successive days. The levels of the factors, coded as -1 (low), 0 (central point), and +1 (high), are shown in Table 1 . The ratio of enzyme to the substrate was kept constant at $0.5 \% w / w$ solid.

Table 1. Levels of factors evaluated on the hydrolysis process optimisation.

\begin{tabular}{ccc}
\hline Factors & Low & High \\
\hline $\mathrm{X}_{\mathrm{A}}: \mathrm{pH}$ & 4.0 & 7.2 \\
$\mathrm{X}_{\mathrm{B}}:$ Temperature $\left({ }^{\circ} \mathrm{C}\right)$ & 25.0 & 45.0 \\
$\mathrm{X}_{\mathrm{C}}:$ Time $(\min )$ & 30.0 & 270.0 \\
\hline
\end{tabular}




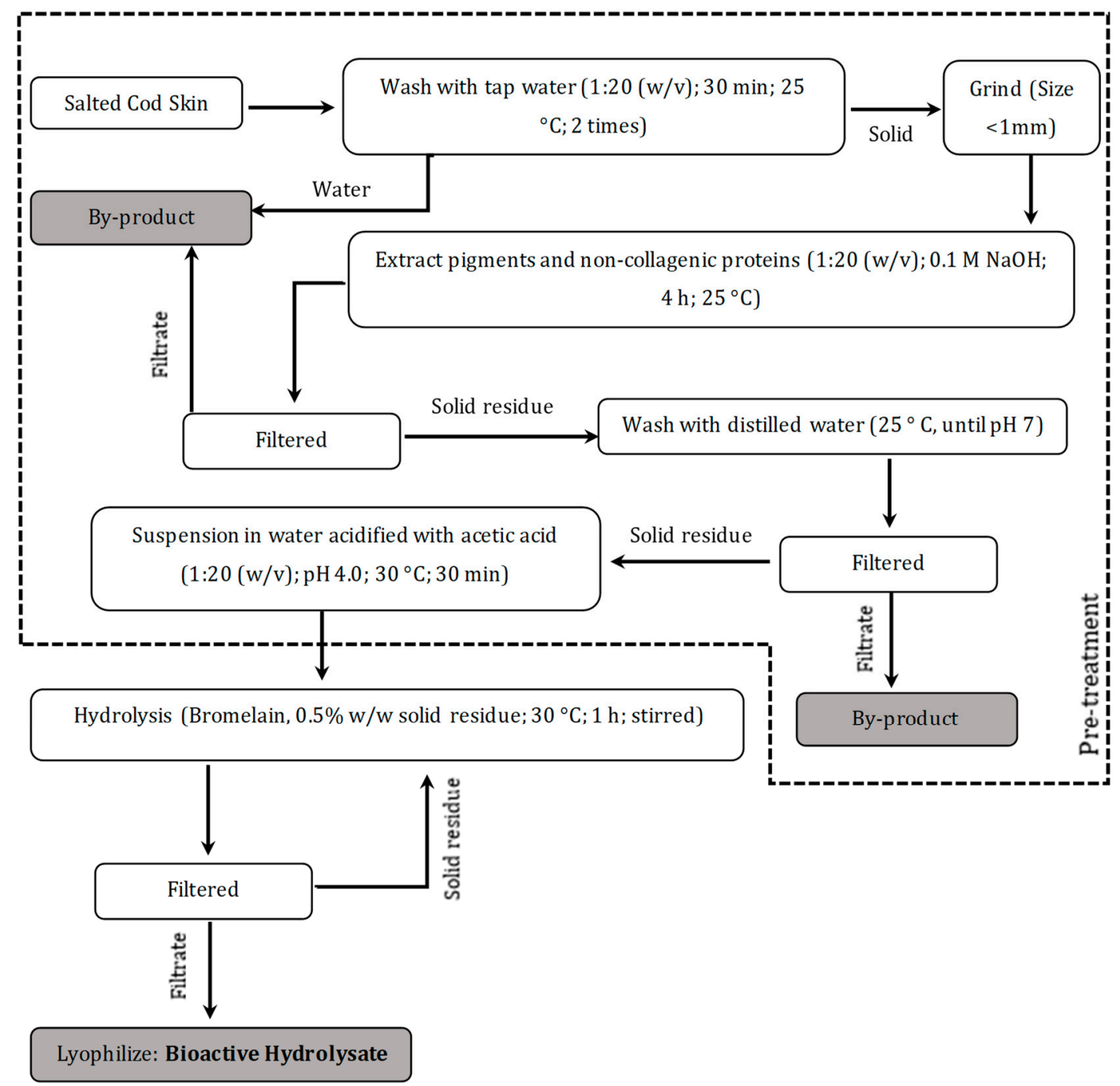

Scheme 1. Optimised process. Flow diagram of the optimal process proposed to produce the bioactive hydrolysates from SCCS.

\subsection{Bioactivities}

The analysis of the antioxidant activity was performed following the methodology described previously [25]. ORAC values were expressed as $\mu$ mol TE (Trolox equivalent)/g protein. The antihypertensive activity was assayed by the inhibitory activity on the angiotensin-I converting enzyme (iACE) as described previously [26]. iACE was expressed as \% inhibition for optimisation tests and as the concentration capable of inhibiting 50\% of the enzymatic activity $\left(\mathrm{IC}_{50}\right)$ for the optimal hydrolysate. Both assays were realised with the multidetection plate reader Synergy H1 (BioTek Instruments, Winooski, VT, USA) controlled by the Gen5 BioTek software version 3.04.

\subsection{In Vitro Biocompatibility}

Two different cell lines were considered throughout this work, namely, mouse fibroblast cells_L929 (NCTC) (ECACC 85103115); and human keratinocyte-HaCaT (300493, CLS, Eppelheim, Germany). L929 and HaCaT cells were cultured in DMEM high glucose supplemented with $10 \%(v / v)$ FBS and $1 \%(v / v)$ penicillin-streptomycin. The tests were carried out following the same procedure that we previously reported [27]. The culture media were carefully removed and replaced with $1 \mathrm{mg}$ hydrolysate $\mathrm{mL}^{-1}$ (sterile filtered). The cytotoxicity was evaluated using the PrestoBlue ${ }^{\mathrm{TM}}$ HS Cell Viability assay (Thermo Scientific, Waltham, MA, USA), following the protocol described by the manufacturer. 
Fluorescence was measured using a fluorescence excitation wavelength of $560 \mathrm{~nm}$ and an emission of $590 \mathrm{~nm}$ by the multidetection plate reader Synergy H1 (BioTek Instruments, Winooski, VT, USA) controlled by the Gen5 BioTek software version 3.04. The metabolic inhibition was determined as previously reported [27].

\subsection{Statistical Analysis}

\subsubsection{Preliminary Analysis}

Since in the data obtained, the response variables were recorded more than once on the same experimental unit, the analysis is considered as "repeated measures", applying then the procedure of Generalised Linear Models, GLM [28]. Each experiment was performed in duplicate.

The mean values were analysed statistically by one-way analysis of variance (ANOVA) followed by Tukey's post hoc test $[29,30]$. Separation of means was conducted by the least significant difference at the $5 \%$ probability level.

\subsubsection{Optimisation}

The process optimisation was carried out in triplicate of the design, expressing the results as mean values with standard deviations (SD). The responses $(\mathrm{Y})$ were fitted to the following polynomial quadratic model:

$$
Y=\beta_{0}+\beta_{A} X_{A}+\beta_{B} X_{B}+\beta_{C} X_{C}+\beta_{A, A} X_{A}^{2}+\beta_{A, B} X_{A} X_{B}+\beta_{A, C} X_{A} X_{C}+\beta_{B, B} X_{B}^{2}+\beta_{B, C} X_{B} X_{C}+\beta_{C, C} X_{C}^{2}+\varepsilon
$$

where $X_{A}$ and $X_{B}$ are the coded levels of the independent variables mentioned above; $\beta_{0}, \beta_{i}, \beta_{i, I}$, and $\beta_{i, j}$ are the regression coefficients for the independent term, the linear, quadratic, and binary interaction effects respectively; and $\varepsilon$, the residual error [31,32]. Following the polynomial model, surface and contour plots of each response were generated. The significance of the effects of each experimental factor was estimated for the model of each response. The regression models that best explained the variability of the data (best $\mathrm{R}^{2}$ ) were derived from recalculating the initial models, just considering the significant effects. Finally, a multicriteria optimisation based on the Derringer desirability function [33] was applied to the results of the experimental design, expressing the desirability of each response value on a $0-1$ scale.

The major statistical analysis was carried out with the aid of RStudio V 1.2.1335.

\section{Results}

\subsection{Preliminary Analysis}

The DH determination is the key parameter that determines the functional and biological activity of resultant hydrolysates. In our case, the obtaining of collagen hydrolysate with a plant enzyme such as BR was evaluated in comparison with a known specific enzyme for collagen (CHC), being the used conditions the optimal for CHC [34] but not for BR. As a result, low molecular weight hydrolysates were obtained with a protein concentration that was not different between the two enzymes $(1.5 \mathrm{mg} / \mathrm{mL})$. As shown in Figure 1, the tendency of the DH was similar between both enzymes. However, under the conditions tested, $\mathrm{BR}$ did not reach $\mathrm{CHC}$ levels, which is justified by the conditions used for the experiments. 


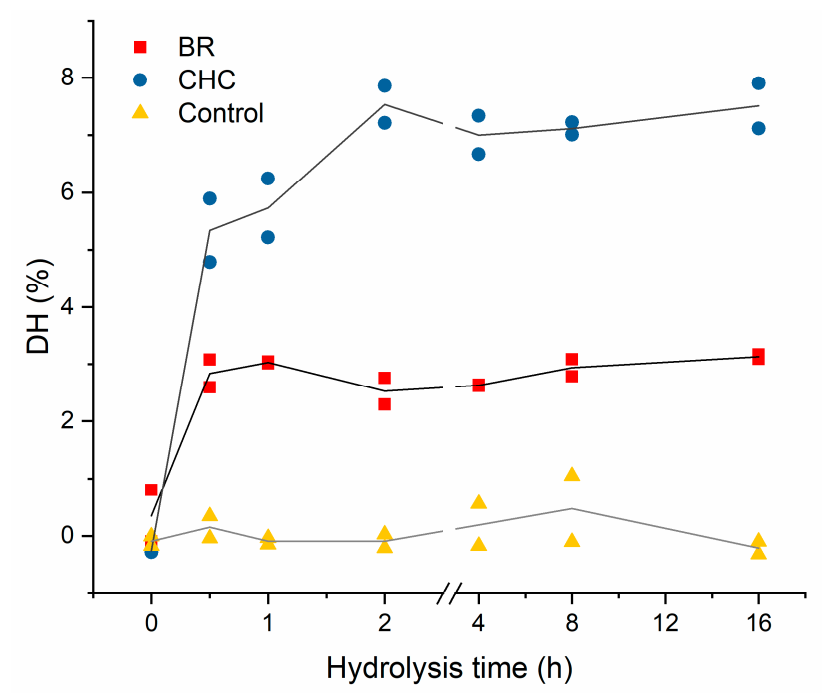

Figure 1. Degree of hydrolysis (DH). DH is expressed in percentage as a function of hydrolysis time expressed in hours. BR: bromelain; CHC: collagenase; Control: without enzyme.

Through the analysis of the electrophoresis (Figure 2), the bands at the initial time (with enzymes) and in the control (without enzyme addition) were compared to the Calfskin type I collagen, which allowed us to see that the main pattern corresponded to the typical for type I collagen. On the other hand, $30 \mathrm{~min}$ later of the hydrolysis processes, the principal bands corresponding to the collagen disappeared, whereas the control remained intact. These results confirmed the successful hydrolysis capacity of BR.

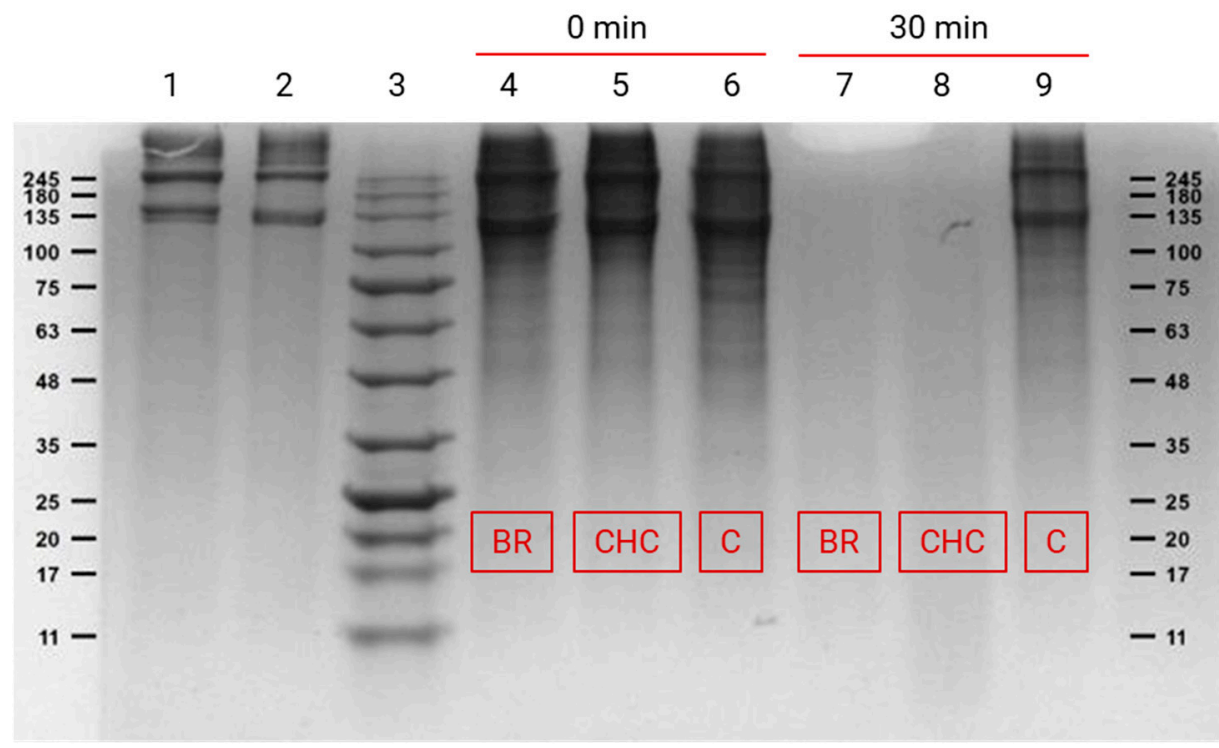

BR: Bromelain | CHC: Collagenase | C: Control

Figure 2. SDS-PAGE: Calfskin type I collagen (lane 1), collagen purified from cod skin by acid methodology (lane 2); molecular weight marker (lane 3); initial time of the hydrolysis with bromelain (lane 4), collagenase (lane 5) and control (lane 6); hydrolysis at $30 \mathrm{~min}$ with bromelain (lane 7), with collagenase (lane 8) and control (lane 9). Molecular weight in kDa.

\subsection{Hydrolysis Optimisation}

When we saw that BR was a good candidate to apply in the production of collagen hydrolysates, we proceeded to design a process that had to be optimised. For this, we carry out an experimental design as described in the methodology. 
Supplementary Materials shows all the data acquired for the design and the complete multifactorial analysis for the 15 randomised treatments. The finally adjusted models explained the variability in a good way, as shown by their determination coefficients $\left(R^{2}\right.$ in Figure 3). Figure 3 shows the standardised effects for the coefficients of the factors of the recalculated models (criterion explained in the methodology). We observed that temperature was a significant factor for the three responses considered. For protein extraction, increasing the temperature increased the response and an important maximising curvature effect.

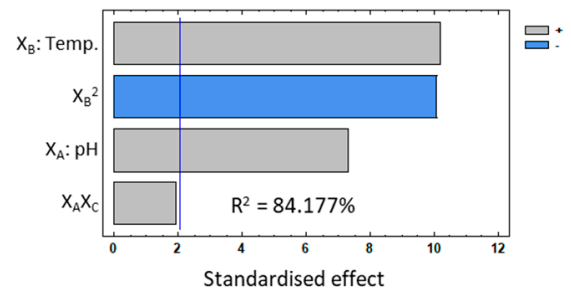

(a)

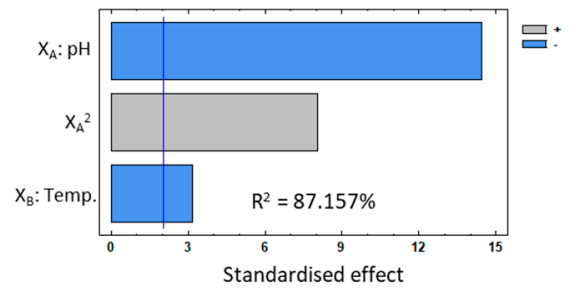

(b)

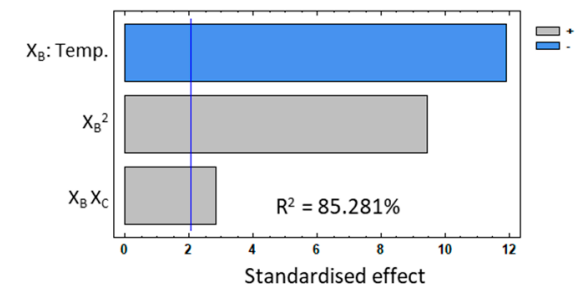

(c)

Figure 3. Analysis of the effects of the Box-Behnken factorial design. Pareto charts with standardised effects of three experimental factors, in decreasing order of importance (in absolute value) for the three responses: protein concentration (a); ORAC (b); and iACE (c). The vertical blue lines represent the threshold of significance $(p=0.05)$ for 32 degrees of freedom.

On the other hand, for bioactivities, the increase in temperature had a negative effect. The $\mathrm{pH}$ effect was significant both for the protein content and antioxidant activity but not for the antihypertensive activity. For protein extraction, increasing the $\mathrm{pH}$ increased the extractive capacity. On the contrary, in antioxidant activity, when the $\mathrm{pH}$ increased, the bioactivity decreased. In the case of the time factor, it was not significant for any of the responses analysed. However, its interaction with temperature was significant in the case of antihypertensive activity; its interaction with $\mathrm{pH}$ was considered in the case of the protein extraction (improved $\mathrm{R}^{2}$ adj).

In a first step, each response was optimised, obtaining different conditions according to the response to maximise (Figure $4 \mathrm{a}-\mathrm{c}$; Table 2). Derringer's total desirability model was applied to carry out general optimisation. Thus, the condition that would allow for the achievement of a good joint maximisation of the responses was reached (Table 3). In the optimal global conditions, the antioxidant activity value (ORAC) is $514 \mu \mathrm{mol}$ Trolox Equivalent/g protein) and the iACE value corresponds to an $\mathrm{IC}_{50}$ of $59 \mu \mathrm{g}$ protein $/ \mathrm{mL}$. From the optimal levels, the validation of the models was carried out, but with a slight modification, instead of $29.8^{\circ} \mathrm{C}, 30.0^{\circ} \mathrm{C}$ was applied, and the predictions were re-entered with these values. Table 3 shows the predicted values for these validation conditions and the observed values for an experiment done in a single execution (for this reason, it does not present any deviation). From the hypothesis test, we did not find significant differences for a confidence level of $5 \%$. Therefore, the models are valid. Besides, by producing the hydrolysate in this condition, a yield of $44 \%$ was achieved. Furthermore, it should be mentioned that, for the hydrolysate produced for the validation, the iACE showed an $\mathrm{IC}_{50}$ of $166 \mu \mathrm{g}$ protein $/ \mathrm{mL}$. This value corresponds to a significant antihypertensive potential $[23,26]$. 


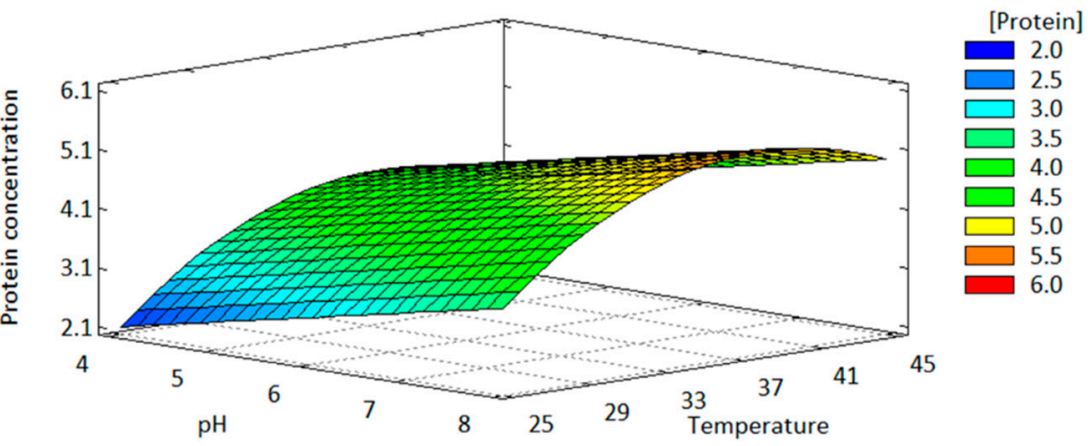

(a)

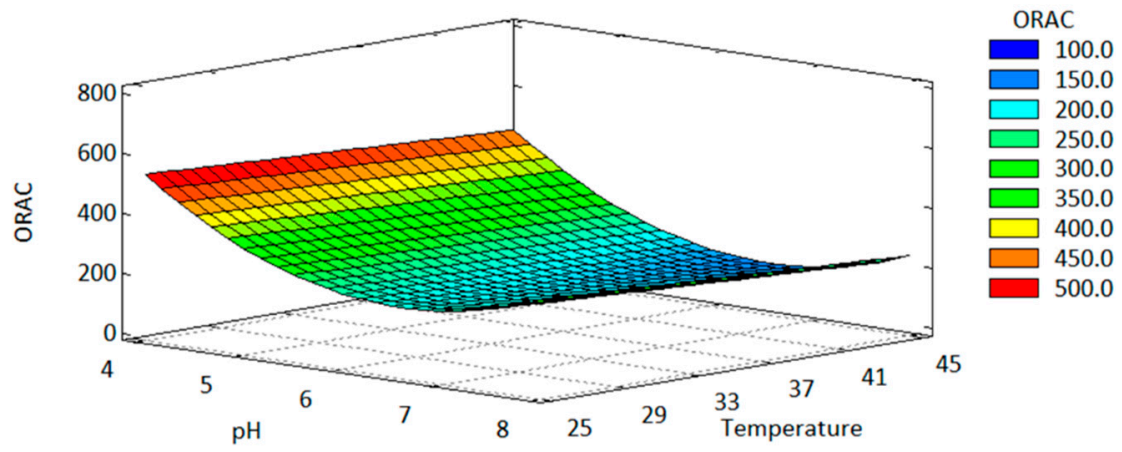

(b)

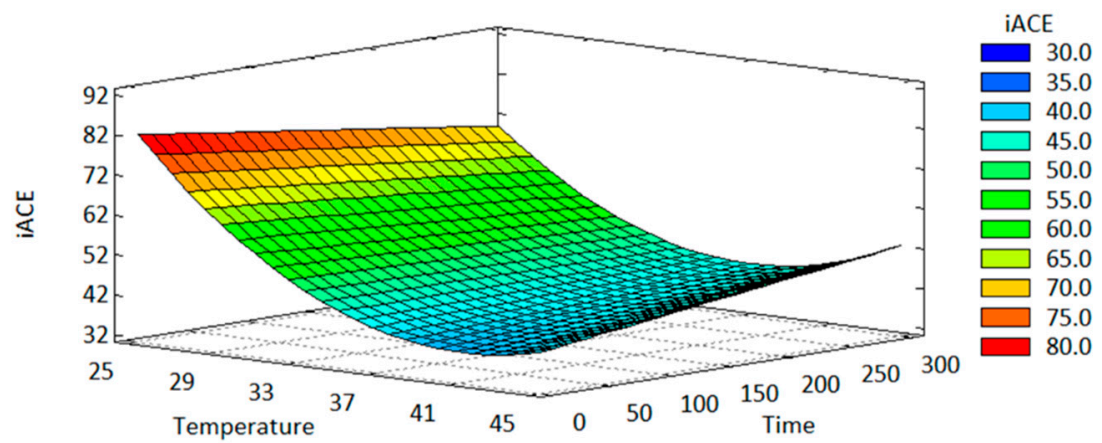

(c)

Figure 4. Response surface models. Each response is based on two experimental factors keeping the third factor at its central level. Charts for: protein concentration (a); ORAC (b); iACE (c).

Table 2. Factor's levels that optimise each response and the corresponding predicted optimal response value.

\begin{tabular}{ccccc}
\hline \multirow{2}{*}{ Model } & \multicolumn{3}{c}{ Factors +} & \multirow{2}{*}{ Response $\ddagger$} \\
\cline { 2 - 4 } & $\mathbf{X}_{\mathbf{A}}$ & $\mathbf{X}_{\mathbf{B}}$ & $\mathbf{X}_{\mathbf{C}}$ & \\
\hline Protein concentration & 7.2 & 38.5 & 270.0 & 5.343 \\
ORAC & 4.0 & 25.0 & 150.0 & 530 \\
iACE & 5.6 & 25.0 & 30.0 & 80.9 \\
\hline
\end{tabular}

${ }^{\dagger}$ Factors: $\mathrm{pH}\left(\mathrm{X}_{\mathrm{A}}\right)$; temperature $\left(\mathrm{X}_{\mathrm{B}}\right)$ expressed in ${ }^{\circ} \mathrm{C}$; time $\left(\mathrm{X}_{\mathrm{C}}\right)$ expressed in min. ${ }^{\ddagger}$ Responses: protein concentration expressed in $\mathrm{mg} / \mathrm{mL}$; ORAC expressed in $\mu \mathrm{mol} \mathrm{TE} / \mathrm{g}$ protein; iACE expressed in $\%$ inhibition $/(0.5 \mathrm{mg} / \mathrm{mL}$ protein). 
Table 3. Derringer optimisation and model validation.

\begin{tabular}{ccc}
\hline Factor $^{\dagger}$ & Optimal \\
\hline $\mathrm{X}_{\mathrm{A}}$ & 4.0 \\
$\mathrm{X}_{\mathrm{B}}$ & 29.8 \\
$\mathrm{X}_{\mathrm{C}}$ & 30.0 \\
& & \\
& & \\
& Optimal desirability: 0.516 & \\
Response ${ }^{\ddagger}$ & Model validation & Observed \\
\hline Protein concentration \pm & Predicted $^{*}$ & 2.2 \\
ORAC & $3.3 \pm 0.7$ & 414 \\
iACE & $517 \pm 92$ & 59 \\
\hline
\end{tabular}

${ }^{\dagger}$ Factors: $\mathrm{pH}\left(\mathrm{X}_{\mathrm{A}}\right)$; temperature $\left(\mathrm{X}_{\mathrm{B}}\right)$ expressed in ${ }^{\circ} \mathrm{C}$; time $\left(\mathrm{X}_{\mathrm{C}}\right)$ expressed in min. ${ }^{\ddagger}$ Responses: protein concentration expressed in $\mathrm{mg} / \mathrm{mL}$; ORAC expressed in $\mu \mathrm{mol}$ TE/g protein; iACE expressed in $\%$ inhibition $/(0.15 \mathrm{mg} / \mathrm{mL}$ protein). ${ }^{*}$ Values expressed as mean $\pm \mathrm{SD}$ of three replicates.

\subsection{Biocompatibility Assay}

The biocompatibility of the hydrolysates was also tested at a protein concentration of $1 \mathrm{mg} / \mathrm{mL}$ in murine fibroblast cells (L929) and immortalised human keratinocytes (HaCaT). In the test, we found that the hydrolysate in the tested concentration was not cytotoxic for any of the cell lines. As shown in Figure 5, negative values prevail for both lines, indicating a possible stimulation of cellular metabolism.

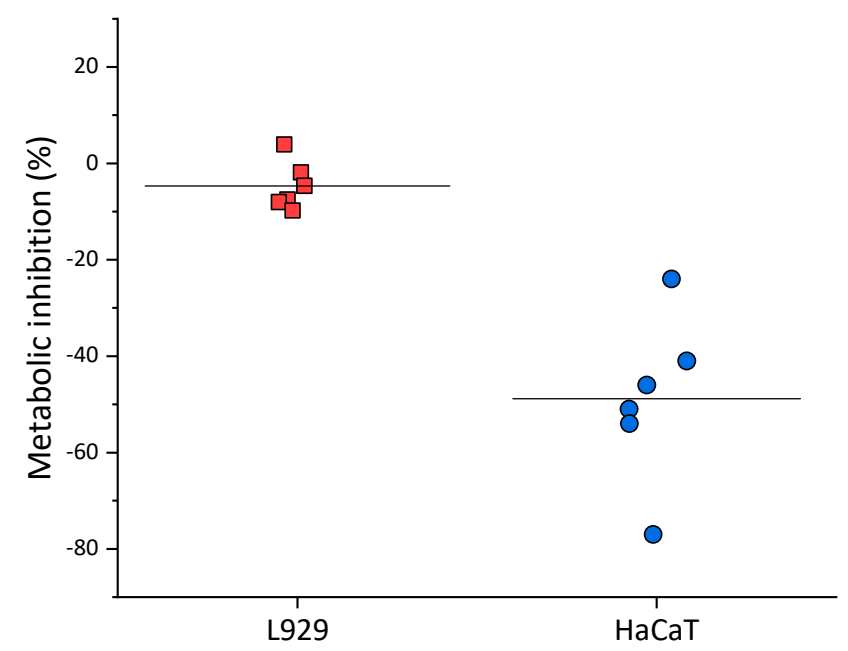

Figure 5. Metabolic inhibition of optimal hydrolysate with a concentration of $1 \mathrm{mg} / \mathrm{mL}$ for $24 \mathrm{~h}$ against two mammalian cell lines, namely: human keratinocyte HaCaT cells; and mouse fibroblast L929 cells. Each boxplot represents $n=6$.

\section{Discussion}

This study aimed to develop a new integrated methodology to produce a collagen-rich enzymatic hydrolysate from SCCS sustainably and simply. On the one hand, enzymatic hydrolysis is the best way to hydrolyse fish skin without losing nutritional and healthy values [35]. On the other hand, the increased fish processing sector results in massive production of waste, which makes it a challenge to dispose of these materials to optimise value and reduce environmental impact [36]. So, in the first step, we compared the BR hydrolysis capacity to $\mathrm{CHC}$, a specific protease for collagen. $\mathrm{BR}$ is a vegetal cysteine endopeptidase with broad specificity used for many industrial applications [12] and was already proved to be effective in hydrolysed collagens [37]. BR was also successfully applied to collagen extraction from the skin of bigeye tuna (Thunnus obesus). It showed the highest collagen yield between other proteases (papain, pepsin, and trypsin) with excellent chemical properties and antioxidant activity [38]. 
Furthermore, Elavarasan et al. [11] found that BR (10.62\%) had the second-best DH $(\%)$ of water-washed catla meat in the optimum conditions after the commercial enzyme protamex (12.61\%). In another case, Sadabpong et al. [39] found that the BR was between the best enzymes for the hydrolysis $(50.59 \% \mathrm{DH})$ of gelatine extracted from Nile tilapia skin. Auwal et al. also investigated the hydrolysis of stonefish protein with BR, obtaining $54.62 \%$ of DH's optimum conditions [7]. In our case, although the DH did differ between the enzymes, with BR, proper digestion of the protein material is still obtained. In addition, the electrophoresis for both enzymes showed that BR is an excellent enzyme to obtain low molecular weight peptides from the collagen of cod skin. Low molecular weight collagen hydrolysates are generally thought to exert better bioactivities. However, many factors affect their preparation, such as the long-lived protein property, the strong and tough cross-links, and the presence of Hydroxyproline (Hyp) in the structure that plays a key role in collagen stability [13]. Possibly, since BR is a protease that acts by making random cuts, this property helps to increase the probability of obtaining low molecular weight hydrolysates with greater bioactivities.

Consequently, during the optimisation process, the high value of protein extraction and high antioxidant and antihypertensive activities in the cod collagen-rich enzymatic hydrolysate were found. The optimum conditions were $\mathrm{pH} 4.0$ and temperature $28.9{ }^{\circ} \mathrm{C}$ during $30 \mathrm{~min}$ of hydrolysis. Previously, collagen peptides derived from fish waste were reported to have antioxidative activity $[10,11,40,41]$ and antihypertensive activity $[39,42-44]$. The antioxidant activities of bioactive peptides are mainly due to some aromatic amino acids and histidine. Furthermore, fish collagen peptides are rich in hydrophobic amino acids because of the high percentage of Gly and Pro. These structural characteristics make the marine collagen peptides possess higher antioxidant effects than peptides derived from other proteins [45]. In the present work, we detected great Oxygen radical absorbance capacity (ORAC assay) and inhibitory activity on the angiotensin-I converting enzyme (iACE assay) in the collagen-rich enzymatic hydrolysate of SCCS treated with BR. In addition, if BR is not removed, our final product benefits from the anti-inflammatory properties already reported for this enzyme [46,47].

Regarding the biocompatibility of the SCCS hydrolysate, this showed to be not cytotoxic for any of the cell lines assayed. Other works suggested that fish collagen exhibits comparable biocompatibility to mammal's skin collagen, indicating it might be a potential alternative to type I collagen from mammals in many applications [48,49].

These results suggest that it was possible to obtain, with an enzymatic/mild acid process, collagen hydrolysate from SCCS with potential antioxidant and antihypertensive properties.

\section{Conclusions}

In the present study, we reported an integrated and sustainable methodology to obtain a collagen hydrolysate from SCCS using a plant enzyme as protease, BR. The enzymatic hydrolysis of SCCS suffered the influence of the variables process being the $\mathrm{T}\left({ }^{\circ} \mathrm{C}\right)$ and $\mathrm{pH}$ the most influent on the protein content, antioxidant, and antihypertensive activities. Optimal process conditions: $\mathrm{pH}$ of 4.0 , the temperature of $28.9^{\circ} \mathrm{C}$, and time of $30 \mathrm{~min}$, resulted in high antioxidant activity value (ORAC: $514 \mu \mathrm{mol}$ Trolox Equivalent/g protein) and high iACE value $\left(\mathrm{IC}_{50}: 166 \mu \mathrm{g}\right.$ protein $/ \mathrm{mL}$ ). Furthermore, the biocompatibility assay showed that it was not cytotoxic for L929 and HaCaT cell lines. So, this is a sustainable process that consumes low time and energy and uses an alternative source as raw material. Thus, potential applications as a bioactive peptide source can be evaluated.

Supplementary Materials: The following are available online at https:/ /www.mdpi.com/article/10 .3390/app11188538/s1. 
Author Contributions: Conceptualisation, E.R.C. and M.P.; methodology, E.R.C.; software, E.R.C. and M.E.B.; validation, E.R.C. and M.E.B.; investigation, E.R.C. and M.E.B.; resources, M.P.; writingoriginal draft preparation, E.R.C. and M.E.B.; writing-review and editing, E.R.C., M.E.B., and M.P.; supervision, E.R.C. and M.P.; project administration, M.P.; funding acquisition, M.P. All authors have read and agreed to the published version of the manuscript.

Funding: This research was funded by Foundation for Science and Technology (FCT) through the “MultiBiorefinery" Project (POCI-01-0145-FEDER-016403).

Institutional Review Board Statement: Not applicable.

Informed Consent Statement: Not applicable.

Data Availability Statement: The data presented in this study are available in Supplementary Materials.

Acknowledgments: The authors thank the company Pascoal \& Filhos S.A. for kindly providing the salt-cured cod skin used in this study. Furthermore, the authors thank the CBQF for the institutional support.

Conflicts of Interest: The authors declare no conflict of interest.

\section{References}

1. Karim, A.A.; Bhat, R. Fish gelatin: Properties, challenges, and prospects as an alternative to mammalian gelatins. Food Hydrocoll. 2009, 23, 563-576. [CrossRef]

2. Khiari, Z.; Ndagijimana, M.; Betti, M. Low molecular weight bioactive peptides derived from the enzymatic hydrolysis of collagen after isoelectric solubilization/precipitation process of turkey by-products. Poult. Sci. 2014, 93, 2347-2362. [CrossRef] [PubMed]

3. Khiari, Z.; Rico, D.; Martin-Diana, A.B.; Barry-Ryan, C. Structure elucidation of ACE-inhibitory and antithrombotic peptides isolated from mackerel skin gelatine hydrolysates. J. Sci. Food Agric. 2014, 94, 1663-1671. [CrossRef]

4. Cabeza, L.F.; Taylor, M.M.; DiMaio, G.L.; Brown, E.M.; Marmer, W.N.; Carrió, R.; Celma, P.J.; Cot, J. Processing of leather waste: Pilot scale studies on chrome shavings. Isolation of potentially valuable protein products and chromium. Waste Manag. 1998, 18, 211-218. [CrossRef]

5. Wang, W.; Li, Z.; Liu, J.; Wang, Y.; Liu, S.; Sun, M. Comparison between Thermal Hydrolysis and Enzymatic Proteolysis Processes for the Preparation of Tilapia Skin Collagen Hydrolysates. Czech J. Food Sci. 2013, 31, 1-4. [CrossRef]

6. Ren, J.; Zhao, M.; Shi, J.; Wang, J.; Jiang, Y.; Cui, C.; Kakuda, Y.; Jun, S. Purification and identification of antioxidant peptides from grass carp muscle hydrolysates by consecutive chromatography and electrospray ionization-mass spectrometry. Food Chem. 2008, 108, 727-736. [CrossRef]

7. Auwal, S.M.; Zarei, M.; Abdul-Hamid, A.; Saari, N. Optimization of Bromelain-Aided Production of Angiotensin I-Converting Enzyme Inhibitory Hydrolysates from Stone Fish Using Response Surface Methodology. Mar. Drugs 2017, 15, 104. [CrossRef]

8. Jian-xin, H.U.O.; Zheng, Z. Study on Enzymatic Hydrolysis of Gadus morrhua Skin Collagen and Molecular Weight Distribution of Hydrolysates. Agric. Sci. China 2009, 8, 723-729. [CrossRef]

9. Rodríguez-Díaz, J.C.; Kurozawa, L.E.; Netto, F.M.; Hubinger, M.D. Optimization of the Enzymatic Hydrolysis of Blue Shark Skin. J. Food Sci. 2011, 76, 938-949. [CrossRef]

10. Tanuja, S.; Viji, P.; Zynudheen, A.A.; Joshy, C.G. Composition, functional properties and antioxidative activity of hydrolysates prepared from the frame meat of Striped catfish (Pangasianodon hypophthalmus) Materials \& Methods. Egypt. J. Biol. 2012, 14, 27-35.

11. Elavarasan, K.; Naveen Kumar, V.; Shamasundar, B.A. Antioxidant and functional properties of fish protein hydrolysates from fresh water carp (Catla catla) as influenced by the nature of enzyme. J. Food Process. Preserv. 2014, 38, 1207-1214. [CrossRef]

12. Iffah, Z.; Arshad, M.; Amid, A.; Yusof, F. Bromelain : An overview of industrial application and purification strategies. Appl Microbiol Biotechnol 2014, 98, 7283-7297. [CrossRef]

13. Hong, H.; Fan, H.; Chalamaiah, M.; Wu, J. Preparation of low-molecular-weight, collagen hydrolysates (peptides): Current progress, challenges, and future perspectives. Food Chem. 2019, 301, 125222. [CrossRef]

14. Huang, Y.R.; Shiau, C.Y.; Chen, H.H.; Huang, B.C. Isolation and characterization of acid and pepsin-solubilized collagens from the skin of balloon fish (Diodon holocanthus). Food Hydrocoll. 2011, 25, 1507-1513. [CrossRef]

15. Silva, T.H.; Moreira-Silva, J.; Marques, A.L.P.; Domingues, A.; Bayon, Y.; Reis, R.L. Marine origin collagens and its potential applications. Mar. Drugs 2014, 12, 5881-5901. [CrossRef]

16. Wang, J.; Pei, X.; Liu, H.; Zhou, D. Extraction and characterization of acid-soluble and pepsin-soluble collagen from skin of loach (Misgurnus anguillicaudatus). Int. J. Biol. Macromol. 2018, 106, 544-550. [CrossRef] [PubMed]

17. Sotelo, C.G.; Comesaña, M.B.; Ariza, P.R.; Pérez-Martín, R.I. Characterization of Collagen from Different Discarded Fish Species of the West Coast of the Iberian Peninsula. J. Aquat. Food Prod. Technol. 2016, 25, 388-399. [CrossRef]

18. Kittiphattanabawon, P.; Benjakul, S.; Visessanguan, W. Characterisation of acid-soluble collagen from skin and bone of bigeye snapper (Priacanthus tayenus). Food Chem. 2005, 89, 363-372. [CrossRef] 
19. Sun, L.; Li, B.; Song, W.; Si, L.; Hou, H. Characterization of Pacific cod (Gadus macrocephalus) skin collagen and fabrication of collagen sponge as a good biocompatible biomedical material. Process Biochem. 2017, 63, 229-235. [CrossRef]

20. Coscueta, E.R.; Brassesco, M.E.; Pintado, M. Salt-cured Atlantic cod skin: A sustainable source of acid-soluble type I collagen. Preprints 2021. [CrossRef]

21. Arumugam, G.K.S.; Sharma, D.; Balakrishnan, R.M.; Ettiyappan, J.B.P. Extraction, optimization and characterization of collagen from sole fish skin. Sustain. Chem. Pharm. 2018, 9, 19-26. [CrossRef]

22. Nielsen, P.M.; Petersen, D.; Dambmann, C. Improved Method for Determining Food Protein Degree of Hydrolysis. J. Food Sci. 2001, 66, 642-646. [CrossRef]

23. Coscueta, E.R.; Amorim, M.M.; Voss, G.B.; Nerli, B.B.; Picó, G.A.; Pintado, M.E. Bioactive properties of peptides obtained from Argentinian defatted soy flour protein by Corolase PP hydrolysis. Food Chem. 2016, 198, 36-44. [CrossRef] [PubMed]

24. Schägger, H.; von Jagow, G. Tricine-sodium dodecyl sulfate-polyacrylamide gel electrophoresis for the separation of proteins in the range from 1 to $100 \mathrm{kDa}$. Anal. Biochem. 1987, 166, 368-379. [CrossRef]

25. Coscueta, E.R.; Reis, C.A.; Pintado, M. Phenylethyl Isothiocyanate Extracted from Watercress By-Products with Aqueous Micellar Systems: Development and Optimisation. Antioxidants 2020, 9, 698. [CrossRef] [PubMed]

26. Coscueta, E.R.; Campos, D.A.; Osório, H.; Nerli, B.B.; Pintado, M. Enzymatic soy protein hydrolysis: A tool for biofunctional food ingredient production. Food Chem. X 2019, 1, 100006. [CrossRef] [PubMed]

27. Coscueta, E.R.; Sousa, A.S.; Reis, C.A.; Pintado, M. Chitosan-olive oil microparticles for phenylethyl isothiocyanate delivery: Optimal formulation. PLoS ONE 2021, 16, e0248257. [CrossRef] [PubMed]

28. Vittinghoff, E.; Glidden, D.V.; Shiboski, S.C.; McCulloch, C.E. Regression Methods in Biostatistics, 2nd ed.; Statistics for Biology and Health; Springer: Boston, MA, USA, 2012; ISBN 978-1-4614-1352-3.

29. Kutner, M.H.; Nachtsheim, C.J.; Neter, J.; Li, W. Applied Linear Statistical Models, 5th ed.; McGraw Hill: New York, NY, USA, 2005.

30. Tukey, J.W. Comparing individual means in the analysis of variance. Biometrics 1949, 5, 99-114. [CrossRef]

31. Gunst, R.F. Response Surface Methodology: Process and Product Optimization Using Designed Experiments. Technometrics 1996, 38, 284-286. [CrossRef]

32. Coscueta, E.R.; Pellegrini Malpiedi, L.; Nerli, B.B. Micellar systems of aliphatic alcohol ethoxylates as a sustainable alternative to extract soybean isoflavones. Food Chem. 2018, 264, 135-141. [CrossRef] [PubMed]

33. Derringer, G.C.; Suich, R. Simultaneous Optimization of Several Response Variables. J. Qual. Technol. 1980, 12, 214-219. [CrossRef]

34. Mandl, I.; Zipper, H.; Ferguson, L.T. Clostridium histolyticum Collagenase: Its Purification and Properties. Arch. Biochem. Biophys. 1958, 74, 465-475. [CrossRef]

35. Huang, C.Y.; Wu, C.H.; Yang, J.I.; Li, Y.H.; Kuo, J.M. Evaluation of iron-binding activity of collagen peptides prepared from the scales of four cultivated fishes in Taiwan. J. Food Drug Anal. 2015, 23, 671-678. [CrossRef] [PubMed]

36. Nawaz, A.; Li, E.; Irshad, S.; Xiong, Z.; Xiong, H.; Shahbaz, H.M.; Siddique, F. Valorization of fi sheries by-products : Challenges and technical concerns to food industry. Trends Food Sci. Technol. 2020, 99, 34-43. [CrossRef]

37. Ketnawa, S.; Rawdkuen, S.; Chaiwut, P. Two phase partitioning and collagen hydrolysis of bromelain from pineapple peel Nang Lae cultivar. Biochem. Eng. J. 2010, 52, 205-211. [CrossRef]

38. Devita, L.; Nurilmala, M.; Lioe, H.N.; Suhartono, M.T. Chemical and Antioxidant Characteristics of Skin-Derived Collagen Obtained by Acid-Enzymatic Hydrolysis of Bigeye Tuna (Thunnus obesus). Mar. Drugs 2021, 19, 222. [CrossRef]

39. Choonpicharn, S.; Jaturasitha, S.; Rakariyatham, N.; Suree, N.; Niamsup, H. Antioxidant and antihypertensive activity of gelatin hydrolysate from Nile tilapia skin. J. Food Sci. Technol. 2015, 52, 3134-3139. [CrossRef] [PubMed]

40. Nikoo, M.; Benjakul, S.; Ehsani, A.; Li, J.; Wu, F.; Yang, N. Antioxidant and cryoprotective effects of a tetrapeptide isolated from Amur sturgeon skin gelatin. J. Funct. Foods 2014, 7, 609-620. [CrossRef]

41. Ngo, D.; Qian, Z.; Ryu, B.; Park, J.W.; Kim, S. In vitro antioxidant activity of a peptide isolated from Nile tilapia (Oreochromis niloticus) scale gelatin in free radical-mediated oxidative systems. J. Funct. Foods 2010, 2, 107-117. [CrossRef]

42. Ngo, D.; Ryu, B.; Vo, T.; Himaya, S.W.A.; Wijesekara, I.; Kim, S. Free radical scavenging and angiotensin-I converting enzyme inhibitory peptides from Pacific cod (Gadus macrocephalus) skin gelatin. Int. J. Biol. Macromol. 2011, 49, 1110-1116. [CrossRef]

43. Phillips, M. Functional and potential therapeutic ACE-inhibitory peptides derived from bromelain hydrolysis of trevally proteins. J. Funct. Foods 2015, 14, 716-725. [CrossRef]

44. Cheung, I.W.Y.; Li-chan, E.C.Y. Enzymatic production of protein hydrolysates from steelhead (Oncorhynchus mykiss) skin gelatin as inhibitors of dipeptidyl-peptidase IV and angiotensin-I converting enzyme. J. Funct. Foods 2017, 28, 254-264. [CrossRef]

45. Cheung, R.; Ng, T.; Wong, J. Marine Peptides: Bioactivities and Applications. Mar. Drugs 2015, 13, 4006-4043. [CrossRef] [PubMed]

46. Jude, C.; Tochukwu, U.; Nwagu, N.T.; Thaddeus, T. Enhancement of the Anti-inflammatory Effect of Bromelain by Its Immobilization on Probiotic Spore of Bacillus cereus. Probiotics Antimicrob. Proteins 2021, 13, 847-861. [CrossRef]

47. Sharma, M.; Sharma, R. Implications of designing a bromelain loaded enteric nanoformulation on its stability and antiinflammatory potential upon oral administration. RSC Adv. 2018, 8, 2541-2551. [CrossRef]

48. Song, E.; Yeon, S.; Chun, T.; Byun, H.; Moo, Y. Collagen scaffolds derived from a marine source and their biocompatibility. Biomaterials 2006, 27, 2951-2961. [CrossRef]

49. Tang, J.; Saito, T. Biocompatibility of Novel Type I Collagen Purified from Tilapia Fish Scale: An In Vitro Comparative Study. Biomed. Res. Int. 2015, 2015, 139476. [CrossRef] 